\title{
PENGARUH BIRO PERJALANAN WISATA SEBAGAI SALURAN DISTRIBUSI TERHADAP TINGKAT HUNIAN KAMAR PADA HOTEL ALL SEASONS LEGIAN BALI
}

\author{
Ni Made Adi Yanti Putri \\ I GPB. Sasrawan Mananda \\ Ni Putu Eka Mahadewi \\ Email : dyantipoetri@yahoo.com \\ PS. S1 Industri Perjalanan Wisata \\ Fakultas Pariwisata UNUD
}

\begin{abstract}
The background of this study was based on of technology development that affect the online or offline room sales at All Seasons Legian Bali. Room sales are made through online travel agents is higher than the offline travel agents. It means the influence of offline travel agent is lower than the growth online travel agent. The purpose of this report is to determine the influence of travel agents as a distribution channel about rooms sales at All Seasons Legian Bali Hotel.

The data were collected by observation, interviews, library research and documentations. Type of data were used in this research are qualitative and quantitative. The data sources were used are the primary and secondary data and the purposive sampling methods to determine the informant. The data were analyzed with the simple regression analysis techniques, simple correlation analysis, analysis of determination, $t$ test with significant level of five percent. The data processing were using with SPSS (Statistical Package for Social Science) 16.00 for windows.

Based on the calculation, The lowest room sales is 247 in the period of May 2009, while the highest room sales is 2.239 in the period of January 2012, and obtained a correlation is $3.9 \%$, which means the relationship between the travel agent and level of room sales at All Seasons Legian is low.

The suggestion could be given that the hotel should strengthen in relationship with travel agents, so that could to provide great contribution as a distribution channel in room sales at All Seasons Legian Hotel .
\end{abstract}

\section{Keywords: Offline Travel Agent, Online Travel Agent, Room Occupancy.}

\section{PENDAHULUAN}

Indonesia merupakan negara kepulauan yang memiliki keanekaragaman budaya, keramah-tamahan masyarakat, serta kekayaan flora dan fauna yang sangat indah dan juga memiliki potensi yang sangat besar untuk menjadi salah satu tujuan wisata dunia. Indonesia mengandalkan pariwisata sebagai salah satu sektor andalan dalam pembangunan, dapat dibuktikan bahwa pariwisata telah memberikan kontribusi penyumbang devisa yang besar bagi Negara. Perkembangan pariwisata Indonesia telah menyebar kesemua daerah termasuk Bali. Bali merupakan salah satu destinasi dengan keunikan budaya dan panorama alamnya yang indah yang mampu menjadi daya tarik bagi wisatawan.

Saat ini pergerakan wisatawan semakin cepat karena adanya faktor-faktor yang mendorong wisatawan untuk melakukan perjalanan wisata, seperti adanya keinginan untuk terlepas dari kehidupan rutin sehari-hari dan memiliki keingintahuan terhadap suatu daerah tujuan wisata. Terkait dengan hal tersebut bali merupakan salah satu daerah tujuan wisata yang memiliki sarana kepariwisataan yang memadai seperti terciptanya sarana pokok (travel agent, restaurant, transportation, accomodation), sarana pelengkap (lapangan tenis, lapangan golf, kolam renang), dan sarana penunjang (night club, casino, spa). Hal tersebut dapat 
dilihat dari perkembangan dan bertumbuhnya sarana pokok kepariwisataan yang semakin meningkat seperti akomodasi yaitu hotel.

Industri perhotelan merupakan salah satu industri yang memiliki pengaruh besar dalam perkembangan dan kedatangan wisatawan sebagai sarana pokok yang bertujuan agar wisatawan tinggal lebih lama dan memiliki kenyamanan selama tinggal, sehingga mampu memberikan kesan yang positif bagi wisatawan untuk berkunjung kembali.

Hal tersebut dapat dilihat pada Tabel 1.2 wisatawan yang menggunakan jasa hotel berdasarkan lima tahun terakhir sebagai berikut. Pada Tabel 1.2 dibawah dapat diketahui bahwa terjadinya fluktuasi pada tingkat pertumbuhan tahun 2010 sampai 2011. Hal tersebut dikarenakan virus flu burung yang tersebar di Indonesia dan menyebabkan kematian. Namun, terjadinya peningkatan pada tingkat pertumbuhan wisatawan mancanegara dan domestik yang menggunakan jasa hotel berbintang pada tahun 2012 sampai 2013. Hal tersebut dikarenakan banyak diselenggarakan eventevent internasional seperti ajang pemilihan Miss World, Asia-Pasific Economic Coorperation (APEC), dan World Tourim Organization (WTO) atau event-event lainnya. Berdasarkan data tersebut dilihat bahwa terjadinya tingkat pertumbuhan yang paling tinggi pada tahun 2013. Melihat hal tersebut, maka pihak-pihak hotel berlombalomba untuk menarik minat wisatawan untuk menginap di tempat mereka. Hampir semua pihak hotel di bali melakukan kerjasama yang saling menguntungkan dengan agen perjalanan. Salah satu hotel yang bekerjasama dengan agen perjalanan adalah Hotel All Seasons Legian Bali.

Namun seiring perkembangan jaman, kemajuan teknologi yang semakin canggih mempengaruhi penjualan kamar yang dilakukan secara online ataupun offline di hotel All Seasons Legian Bali. Hal ini dijelaskan pada tabel 1.3 bahwa penjualan yang dilakukan melalui biro perjalanan wisata online lebih tinggi dari pada biro perjalanan wisata offline hal ini disebabkan karena pemesanan yang dilakukan oleh konsumen lebih praktis. Saat ini terdapat banyak sekali situs-situs yang menyediakan jasa media pemesanan kamar secara online. Kehadiran biro perjalanan wisata online ini sangat mempengaruhi dunia pariwisata dan menguntungkan bagi pihak hotel dalam segi penghematan biaya promosi.

Banyak pihak-pihak yang bekerjasama dengan Hotel All Seasons Legian Bali yang paling menarik perhatian adalah biro perjalanan wisata online dan biro perjalanan wisata yang dalam operasionalnya untuk memenuhi room occupancy. Bagi pihak hotel bekerjasama dengan biro perjalanan wisata online dan offline merupakan suatu keuntungan bagi pihak Hotel All Seasons Legian Bali. Dapat dilihat pada Tabel 1.3 tingkat penjualan yang dilakukan melalui biro perjalanan wisata online ataupun biro perjalanan wisata offline pada Hotel All Seasons Legian.

Berdasarkan Tabel 1.3 di atas dapat dikatakan bahwa penjualan kamar yang dilakukan oleh biro perjalanan wisata online dan biro perjalanan wisata offline mengalami penurunan pada tingkat pertumbuhan setiap tahunnya dari tahun 2009 sampai 2013. Tetapi berdasarkan jumlah penjualan kamar yang dilakukan melalui biro perjalanan wisata online terjadi peningkatan setiap tahunnya sedangkan penjualan yang dilakukan melalui biro perjalanan wisata offline menurun setiap tahunnya. Walaupun tahun 2009 sampai 2013 penjualan kamar didominasi melalui biro perjalanan wisata offline.

Oleh karena itu, untuk mengetahui bagaimanan pengaruh biro perjalanan wisata dalam meningkatan hunian kamar pada Hotel All Seasons Legian Bali, maka dilakukan penelitian pada analisis pengaruh biro perjalnan wisata sebagai saluran distribusi terhadap tingkat hunian kamar pada Hotel All Seasons Legian Bali yang dihitung perbulan dari tahun 2009-2013.

\section{TINJAUAN PUSTAKA}

Travel Agent menurut Goeldner (2009) Travel agent atau Biro Perjalanan Wisata adalah perantara sebuah bisnis atau seseorang yang menjual bagian-bagian tertentu dalam industri pariwisata secara individual atau kombinasi dari bagian-bagian tersebut kepada konsumen.

Perbedaan biro perjalanan wisata da travel agent dapat dilihat dari tugas masingmasing. Biro perjalanan wisata bertugas merencanakan dan menciptakan perjalanan, mendapatkan keuntungan berdasarkan hasil 
dari penjualan perencanaan yang diciptakan seadangan travel agent bertugas sebagai perantara perjalanan dan mendapatkan keuntugan dari komisi, dan tiping. Travel Agent dilihat dari pangsa pasar dibagi menjadi dua yaitu offline travel agent dan Online Travel Agent.

Basu Swastha (1999) mengatakan bahwa tingkat penjualan adalah jumlah yang ditawarkan dari sebuah perusahaan oleh pemakai industri dengan menggunakan distributor.

Berdasarkan pendapat Endar Sugiarto (1996) Hotel adalah suatu bentuk bangunan, lambang, perusahaan atau badan usaha akomodasi yang menyediakan pelayanan jasa penginapan, penyedia makanan dan minuman serta fasilitas jasa lainnya dimana semua pelayanan itu diperuntukkan bagi masyarakat umum, baik mereka yang bermalam di hotel tersebut ataupun mereka yang hanya menggunakan fasilitas tertentu yang dimiliki hotel itu.

Menurut Philip Kotler (2007), Saluran Distribusi adalah suatu perangkat organisasi yang tercakup dalam suatu proses yang membuat produk atau jasa untuk digunakan atau dikonsumsi oleh konsumen atau pengguna bisnis.

Menurut Yoeti (2001) wisatawan merupakan seseorang, tanpa membedakan ras, kelamin, bahasa, dan agama, yang memasuki wilayah suatu negara yang mengadakan perjanjian yang lain dari pada negara dimana orang itu biasanya tinggal dan berada di situ tidak kurang dari 24 jam dan tidak lebih dari enam bulan, di dalam jangka waktu 12 bulan berturut-turut, untuk tujuan non imigrasi yang legal.

\section{METODE PENELITIAN}

Penelitian ini dilakukan di Hotel All Seasons di Legian-Bali yang berlokasikan di Jalan Padma Utara Legian-Bali sebelah Hotel Padma. Penelitian ini menggunakan data kualitatif dan kuantitatif. Pengumpulan data dilakukan dengan observasi, wawancara, studi pustaka,dan dokumentasi. Teknik penentuan sampel ditentukan dengan metode purposive sampling dan menggunakan analisis SPSS yaitu regresi berganda, korelasi, determinasi, uji F serta uji T.
HASIL DAN PEMBAHASAN

\section{Gambaran Umum Hotel All Seasons Legian}

Perusahaan Group Accor Hotel didirikan oleh Gerard Pelisson dan Paul Dubrule pada Tahun 1983. Group Accor Hotel berdiri di 92 negara, dengan 3.645. Hotel All Seasons Legian adalah salah satu hotel dari Group Accor yang ada di Bali, All Seasons Legian merupakan nama hotel pertama yang ada di Group Accor Hotel di Asia, dibangun di atas lahan seluas $3.775 \mathrm{~m}^{2}$ dan berlokasi di destinasi wisata. Hotel All Seasons di Legian didirikan oleh PT. Bali Sarana Sejahtera dengan pemegang saham terbesar bernama Tjong Wai Kit. Berdasarkan Keputusan Bupati Badung No. 556,51 641/Diparda tanggal 02 agustus 2005, Hotel All Seasons Legian resmi menjadi salah satu hotel bintang tiga yang bergerak dibidang usaha penyediaan akomodasi.

Hotel All Seasons Legian Bali yang secara resmi mulai beroperasi tanggal 10 Oktober 2006 merupakan hotel bintang tiga yang beralamat di Jl. Padma Utara. Hotel All Seasons Legian menawarkan berbagai macam fasilitas diantaranya 113 kamar yang terjadi dalam tipe kamar (superior room, deluxe room, and family room), bar, restoran, spa, swimming pool dan meeting room.

\section{Travel Agent Sebagai Saluran Distribusi Pada Hotel All Seasons Legian}

Saluran distribusi mempunnyai tugas menyalurkan barang-barang atau sebagai perantara dari produsen ke konsumen yang berupa penyalur produk atau jasa yang dijual. Dengan demikian para konsumen akan dapat menikmati dan mendapatkan produk yang mereka butuhkan.

Distribusi memegang peranan penting bagi konsumen. Dengan adanya saluran distribusi yang baik maka dapat menjamin ketersediaan produk yang dibutuhkan oleh konsumen kepada produsen. Tanpa adanya saluran distribusi, produsen akan kesulitan untuk memasarkan produknya dan konsumenpun kesulitan untuk mencari produsen untuk dapat menikmati produknya.

Biro perjalanan wisata merupakan salah satu alat atau perantara yang digunakan Hotel All Seasons Legian sebagai saluran distribusi dalam penjualan kamar/ produk yang dimiliki oleh hotel. Saluran distribusi dalam hal ini diartikan sebagai proses 
perantara untuk menyampaikan barang dari produsen kepada konsumen. Sedangkan biro perjalanan wisata adalah suatu badan usaha yang menjual jasa dalam perjalanan wisata seperti, paket wisata yang tentunya berhubungan dengan transportasi dan akomodasi. Konsumen yang melakukan perjalanan wisata tidak hanya akan melakukan perjalanan saja tentu membutuhkan sebuah tempat untuk beristirahat, yaitu akomodasi. Oleh karena itu biro perjalanan wisata selalu menjual akomodasi dalam paket wisata untuk konsumen.

\section{Pengaruh Biro Perjalanan Wisata sebagai Saluran Distribusi terhadap Tingkat Hunian Kamar di Hotel All Season Legian Bali.}

Berdasarkan perhitungan analisis SPSS versi 16.0 diketahui nilai tingkat penjualan kamar yang terendah yang dilakukan oleh Biro Perjalanan Wisata melalui online adalah 247 room yang merupakan low seasons pada bulan Mei tahun 2009 dan memperoleh tingkat penjualan tertinggi adalah sebesar 1988 room pada bulan September tahun 2009. Sedangkan tingkat penjualan kamar yang dilakukan oleh Biro Perjalanan Wisata Melalui Offline adalah 458 room yang merupakan penjualan yang di dominasi melalui Online pada bulan Desember 2013 dan memperoleh tingkat penjualan yang tertinggi adalah sebesar 2239 room pada bulan Januari 2012 yang disebabkan banyaknya group yang in house.

Berdasarkan perhitungan analisis SPSS 16.0 dapat dilihat Analisis regresi linear berganda digunakan untuk mengetahui pengaruh Biro Perjalanan Wisata sebagai saluran distribusi terhadap tingkat hunian kamar pada Hotel All Seasons Legian Bali.

$\mathrm{Y}=\alpha+\beta_{1} \mathrm{X}_{1}+\beta_{2} \mathrm{X}_{2}$

$\mathrm{Y}=81,66+0,003 \mathrm{X}_{1}+0,004 \mathrm{X}_{2}$

Persamaan diatas mempunai arti sebagai berikut:

a. Nilai Konstanta $=81.664$ apabila kamar Hotel All Seasons Legian tidak terjual oleh Biro Perjalanan wisata baik melaui online ataupun Offline maka tingkat hunian kamar hanya menjadi $81.66 \%$. b. Nilai $X_{1}$, berarti apabila terjadi kenaikan penjualan kamar yang dilakukan oleh Biro Perjalanan Wisata Online, sebanyak satu kamar maka tingkat hunian kamar akan meningkat $0,03 \%$

c. Nilai $X$, berarti apabila terjadi kenaikan penjualan kamar yang dilakukan oleh Biro Perjalanan Wisata Offline sebanyak sat kamar maka tingkat hunian kamar akan meningkat $0,04 \%$.

Berdasarkan perhitungan nilai SPSS versi 16.0 dapat dilihat pada lampiran 3 , sebagaimana terlihat pada Tablel 4.4 diperoleh nilai korelasi berganda sebagai $(\mathrm{r}=0.39)$.

Kuat Lemahnya hubungan antara variable y ( tingkat hunian kamar Hotel All Seasons Legian) dari variaber $\mathrm{X}_{1}$ (Biro Perjalanan Wisata Online) dan $\mathrm{X}_{2}$ (Biro Perjalanan Wisata Offline) yang disebut juga korelasi berganda. Sesuai dengan pedoman (Priyatno, 2010), diketahui nilai koefisien $\mathrm{R}$ sebesar 0,39 mengandung arti bahwa hubungan antara variable-variabel tingkat penjualan kamar yang dilakukan oleh Biro Perjalanan Wisata ( $\mathrm{X}$ )dengan tingkat hunian kamar di Hotel All Seasons Legian (Y) sebesar 0.39 atau mempunyai hubungan yang lemah (Pernomo, 2010).

Dari hasil perhitungan determinasi, dapat diketahui bahwa seberapa besar kemampuan variabel independen menjelaskan variabel dependennya yaitu Biro perjalanan Wisata Online $\left(\mathrm{X}_{1}\right)$ dan Biro Perjalanan Wisata Offline $\left(\mathrm{x}_{2}\right)$ terhadap tingkat hunian kamar (Y) pada Hotel All Seasons Legian.

$\mathrm{D}=r^{2} .100 \%$

$D=(0.39)^{2} .100 \%=15 \%$

Hal ini menunjukan bahwa sebesar $15 \%$ tingkat hunian kamar ditentukan oleh variabel Biro Perjalanan Wisata Online dan Biro Perjalanan Wisata Offline dan sisanya sebesar $85 \%$ dipengaruhi oleh variabel lain seperti adanya penjualan kamar secara direct (telepon, Fax ataupun Email dan walk in guest).

Diketahui nilai determinasi Biro Perjalanan Wisata Online adalah $\mathrm{r}^{2}=0,051$ yang berarti sebesar $5,1 \%$ tingkat hunian kamar dipengaruhi oleh penjualan yang dilakukan oleh Biro Perjalanan Wisata Online sedangkan nilai determinasi Biro 
Perjalanan Wisata Offline adalah $\mathrm{r}^{2}=0,158$ yang berarti sebesar $15,8 \%$ tingkat hunian kamar yang dipengaruhi penjualan yang dilakukan oleh Biro Perjalanan Wisata Offline. Dari hasil determinasi tersebut, diketahui bahwa Biro Perjalanan Wisata Offline yang lebih dominan dan memiliki pengaruh yang lebih kuat terhadap tingkat hunian kamar pada Hotel All Seasons Legian sebesar 15,8\%. Hal ini didukung oleh kerjasama hotel yang baik terhadap Biro Perjalanan Wisata sebagai saluran distribusi, dimana Biro Perjalanan Wisata mampu lebih sering mmberikan group terhadap hotel sehingga dapat meningkatkan tingkat hunian kamar pada Hotel All Seasons Legian. Sedangkan pengaruh Biro Perjalanan Wisata Online hanya $5,1 \%$ memiliki pengaruh yang lebih lemah dari Biro Perjalanan Wisata Offline.

\section{SIMPULAN DAN SARAN Simpulan}

Berdasarkan pembahasan pada hah sebelumnya, adapun hal-hal yang $d$ disimpulkan adalah sebagai berikut.

1. Biro Perjalanan Wisata memiliki hubungan yang lemah terhadap tingkat hunian kamar di Hotel All Seasons Legian Bali.

2. Biro Perjalanan Wisata mampu memberikan 15\% tingkat hunian kamar yang ditentukan oleh variabel Biro Perjalanan Wisata Online dan Biro Perjalanan Wisata Offline dan sisanya sebesar $85 \%$ dipengaruhi oleh variabel lain seperti adanya penjualan kamar secara direct (telepon, Fax ataupun Email dan walk in guest).

3. Biro Perjalanan Wisata offline berpengaruh dominan sebesar $15 \%$ dibandingkan Biro Perjalanan Wisata online sebesar $5,1 \%$ terhadap tingkat penjualan kamar di Hotel All Seasons Legian.

\section{Saran}

Berdasarkan simpulan di atas, maka dapat disarankan hal-hal sebagai berikut :

1. Manajemen Hotel All Seasons Legian Bali harus lebih menigkatkan kerja sama dengan Biro Perjalanan Wisata sehingga dapat mempermudah media promosi dan dapat memberikan dampak positif terhadap tingkat hunian kamar di Hotel All Seasons Legian Bali.

2. Manajemen Hotel All Seasons Legian Bali untuk mencari hal-hal lain di luar Biro Perjalanan Wisata yang memberikan pengaruh yang signifikan (besar) terhadap tingkat hunian kamar, seperti mengadakan MICE, meningkatkan promosi sampai ke mancanegara.

\section{DAFTAR PUSTAKA}

Kotler, Philip. 2007. Manajemen Pemasaran. Edisi 11. Jilid 1. Penerbit : $\mathrm{Pt}$ Gramedia Pustaka Utama, Jakarta.

Endar Sugiarto. 1996. Pengantar Industri Akomodasi dan Restoran. Jakarta:Gramedia Pustaka Utama.

Pendit, Nyoman S. 2004. Ilmu Pariwisata, Jakarta: Pradnya Paramita.

Swatha Basu DH, 1999. Saluran Pemasaran, BPFE Yogyakarta.

Goeldner. 2009. Tourism: Principle, Practices, Philosophies.

Yoeti, Oka A. 2001. Tours and Travel Management, Jakarta:PT. Pradnya Paramita. 